apuntesuniversitarios.upeu.edu.pe

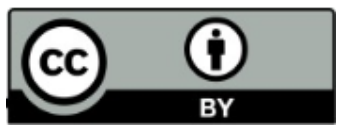

Apuntes Universitarios, 2020: 10(4), octubre-diciembre

ISSN: 2304-0335 DOI:https://doi.org/10.17162/au.v10i4.522

\title{
Valores morales de la organización basados en patrones morales comerciales y requisitos legales para presentar el modelo en la administración tributaria
}

\section{Moral values of organization based on business moral patterns and legal requirements for presenting model in tax administration}

\author{
Yousef Mehni ${ }^{1 a}$, Saeed Sayadi ${ }^{2}$, Masoud Pourkiani $^{3}$, Sanjar Salajegheh $^{4}, \&$ \\ Hojat Babaei $^{5}$ \\ Islamic Azad University, Kerman, Iran ${ }^{12345}$ \\ iD Orcid ID: https://orcid.org/0000-0003-3460-4075 \\ Orcid ID: https://orcid.org/0000-0003-2917-90432 \\ Orcid ID: https://orcid.org/0000-0002-5370-37683 \\ Orcid ID: https://orcid.org/0000-0002-3412-6731 \\ Orcid ID: https://orcid.org/0000-0002-8084-4507
}

Recibido: 19 de febrero de 2020

Aceptado: 12 de agosto de 2020

\section{Resumen}

El propósito de esta investigación fue analizar y explicar los valores éticos de la organización basados en modelos éticos comerciales y requisitos legales para presentar un modelo en la Administración Tributaria de Kerman (Irán). La presente investigación es descriptiva y exploratoria, y de tipo combinado (cuantitativo, cualitativo). Por lo tanto, la orientación de esta investigación fue primero determinar e identificar los componentes de los valores éticos de la organización, además de revisar la literatura y los antecedentes de la investigación. El método de muestreo cualitativo exploratorio y el tamaño de la muestra debido a las limitaciones de acceso se consideran para esta etapa 11 personas. Este grupo incluye gerentes y empleados de la Administración Tributaria de Kerman. Según las estadísticas, hay 727 gerentes y empleados de la Administración Tributaria de Kerman. Debido a que el tipo de investigación requiere información de individuos específicos, es decir, tipos específicos de personas como gerentes (19) y empleados (708) que pueden proporcionar la información deseada en la investigación, fueron seleccionados como muestra estadística. La validez del cuestionario fue confirmada por análisis factorial exploratorio y confirmatorio y la confiabilidad del cuestionario fue confirmada por el alfa de Cronbach. En la presente investigación, los valores éticos incluyen justicia organizacional, compromiso organizacional, cultura moral empresarial y responsabilidad social de una organización. Los patrones de la moral del trabajo incluyen la moral profesional, la moral social y la moral individual, y los requisitos legales incluyen los servicios apropiados, la calidad de los servicios y la confianza. En el caso del modelo de medición de valores éticos basado en patrones éticos y requisitos legales en la provincia de Kerman, la correlación entre variables no es más de 0.9. Por lo tanto, no es necesario fusionarlos o eliminarlos. Además, todas las cargas de factor son mayores que 0.5 , lo que indica que todas las dimensiones tienen una buena validez 
de factor. Con respecto al modelo estructural de valores éticos basado en patrones éticos y requisitos legales en la administración tributaria de la provincia de Kerman, la relación entre la variable de modelos éticos organizacionales y los valores morales empresariales es positiva y significativa. También existe una relación positiva y significativa entre la variable de requisitos legales y los valores éticos de la organización.

Palabras clave: Valores morales organizacionales, patrones morales de negocios, requisitos legales, justicia organizacional, compromiso organizacional, responsabilidad social de la organización.

\begin{abstract}
The purpose of this research was to analyze and explain the organization's ethical values based on ethical business models and legal requirements to present a model to the Kerman Tax Administration (Iran). The present investigation is descriptive and exploratory, and of a combined type (quantitative, qualitative). Therefore, the orientation of this research was first to determine and identify the components of the organization's ethical values, in addition to reviewing the literature and the research background. The exploratory qualitative sampling method and the sample size due to access limitations are considered for this stage 11 people. This group includes managers and employees of the Kerman Tax Administration. According to statistics, there are 727 managers and employees of the Kerman Tax Administration. Because the type of research requires information from specific individuals, that is, specific types of people such as managers (19) and employees (708) who can provide the desired information in the research, they were selected as a statistical sample. The validity of the questionnaire was confirmed by exploratory and confirmatory factor analysis and the reliability of the questionnaire was confirmed by Cronbach's alpha. In this research, ethical values include organizational justice, organizational commitment, corporate moral culture, and social responsibility of an organization. Patterns of work morale include professional morale, social morale, and individual morale, and legal requirements include appropriate services, quality of services, and trust. In the case of the ethical values measurement model based on ethical standards and legal requirements in the Kerman province, the correlation between variables is not more than 0.9. Therefore, there is no need to merge or remove them. Furthermore, all factor loads are greater than 0.5 , indicating that all dimensions have good factor validity. Regarding the structural model of ethical values based on ethical patterns and legal requirements in the tax administration of the Kerman province, the relationship between the variable of organizational ethical models and the corporate moral values is positive and significant. There is also a positive and significant relationship between the variable of legal requirements and the ethical values of the organization.
\end{abstract}

Keywords: Organizational Moral Values, Business Moral Patterns, Legal Requirements, Organizational Justice, Organizational Commitment, Social Responsibility of Organization.

\title{
Introduction
}

Morality and the preservation of ethical values have become one of the most important phenomena that attract attention in most organizations. Moral principles have become part of the formal policies and informal cultures of organizations. Morality means observing the spiritual principles and values that govern a person or group's behavior in terms of what is right and what is wrong. Moral values determine the standards of what is good or bad in behavior and decision-making. Morality is different from the behavior of the law. Legal behavior is rooted in a set of principles that determine the type of action individuals generally adopt; they are generally acceptable, binding and enforceable in courts (Baharifar \& Javaherifar, 2010). 
The ethical values of senior management have a particular impact on the social responsibility of an organization. Because this system is self-regulating, there are no rules or regulations for it. Therefore, if the organization has a strong ethical approach and wants to work for the betterment of the environment, it will participate in corporate social responsibility. If senior management obeys the right laws in the workplace and this infiltrates downstream management, the organization as a whole will work for society, customers and business partners. Researchers have found that public sector organizations are not heavily involved in corporate social responsibility activities inside and outside the organization because they are concerned about the senior management morality regarding employees and the welfare of society. Senior management does not treat employees well and they are not ethically motivated to do their job and do not consider any harm to the organization and outside the organization. The ethical culture of the organization has a strong impact on employees and their productivity and this culture of employee amorality is transmitted to society (Razaq et al, 2013). These values help to establish and maintain standards that can influence people towards the actions that are desirable for an organization.

Ethical behavior also consists of two main aspects: the ability to distinguish good and bad, right and wrong, commitment and tendency towards doing what is right. Ethical behavior is a reflection of one's values (Khodami \& Oslanloo, 2015). We can divide one's values into the principal ethical values and cultural or individual ethical values. The principal values are the basis for ethical decisions. These values are fundamental regardless of time, culture and religion. These values are usually defined by words such as trustworthiness, respect, responsibility, justice and fairness, social and civil customs. Cultural or individual values are beliefs about what is right or wrong. These beliefs are derived from experience, family values, religious beliefs, cultural traditions, standards, and professional actions. These values are determined by changes in time, context, religion, and individuals (Rahimnia \& Hoshyar, 2010). The ethical behavior and current system of employment relationships in any organization are essential for overall growth, production of goods and services for both domestic and business use, International exchange, political stability, and the full benefits of sustainable human development. In other words, the degree to which organizations are committed to ethical standards determines the welfare and health of all beneficiaries, the organization's productivity, and subsequent profitability, as well as macroeconomic growth and national development. The goal of any organization is to have employees who are consistent with the mission and goals of the company and are committed to their principal values, adhere to ethical rules, and adapt their actions to different beliefs in different contexts. Employee compliance, moral correctness, moral principles, and organizational productivity play an important role. Also integrating the values within the ordinary operations of an organization promotes employees' ethical behavior 
(Adeniji et al., 2015).

The collapse of behavioral standards in the public sector has prompted researchers to seek further theoretical foundations in this regard and to be able to provide an appropriate course of action and improve the ethical and organizational behavior of employees. So, one of the most important concerns of efficacious managers at different levels of the organization is to create the right context for human agents working in all professions so that they work with a sense of responsibility and commitment in their community and profession and adhere to the morality of their profession. The first step in achieving these goals is a proper understanding of the concept of organizational morality and identifying the factors that influence employees' ethical behavior (Arianpour M. \& Mehrabi, 2016).

\section{Theoretical foundations and empirical background of research}

Maintaining morality has become one of the most important phenomena that attract attention in most organizations. Moral principles have become part of the formal policies and informal cultures of organizations. Morality means observing the spiritual principles and values that govern a person or group's behavior in terms of what is right and what is wrong. Moral values determine the standards of what is good or bad in behavior and decision-making. Morality is different from the law. Legal behavior is rooted in a set of principles that determine the type of action individuals generally adopt; they are generally acceptable, binding and enforceable in courts (Baharifar \& Javaherifar, 2010).

\section{Ethical values}

The foundation of all values in the organization is ethical values. These values help to establish and maintain standards that can influence the direction of individuals towards the desired actions for the organization. In particular, organizational success increases when organizational standards or ethical values are widely shared among members. Values are the foundation of any organization's culture. As with the philosophy of the organization for success, values also provide a common path and direction for all employees, as well as guidelines for their daily behavior. Recognizing the importance of values and their relationship to culture, it is necessary to identify the fundamental values that are at the root of the normative foundations of the individual and the organization (Baharifar \& Javaherifar, 2010). In the present research, ethical values include organizational justice, organizational commitment, work ethical culture, and social responsibility of an organization.

\section{Work moral patterns}

Work morality is an important aspect of an organization's culture and is becoming part of an organization's strategy. Morality in work provides the foundation for a business to 
improve working conditions (Mousavi \& Arabshah-Karizi, 2014). Perhaps with the slightest hesitation, the category of morality is one of those concepts and debates that have been the most oppressed. Because every individual or group considers their actions (in most cases and instances) morally justified, explaining at least not labeled immoral or in some way why their behavior is such and such. The ethical justification of actions and the common effort in this direction (which is general) indicate the status of morality, but due to lack of sufficient awareness of its role in transcendence (of individual, group, and organization) and insistence on justifying immoral acts, sometimes we find that morality in the pursuit of individual and group goals and interests is oppressed. Although the word morality has had widely used, the increasing emphasis on it, and especially the emergence of ethical failures in all fields, and especially in the management of organizations, has made it one of the hottest topics of the day. Morality and moral principles are among the subjects that have been emphasized in Islam so that the Prophet (peace be upon him) has introduced the purpose of his mission as fulfilling the moral principles (Ismaili \& Rahimi-Aghdam, 2016). In the present research, business moral patterns include professional morality, social morality, and individual morality.

\section{Legal requirements}

Morality is different from the behavior of the law. Legal requirements are rooted in a set of principles that determine the type of action individuals generally adopt; they are generally acceptable, binding and enforceable in courts. Legal requirements apply to behaviors that do not necessarily fall under the guise of morality. Ethical legal requirements imply the need for morality as well as the management of work morality in today's businesses. Researches have shown that observing ethical legal requirements has a significant impact on promoting organizational goals and enhancing organizational performance. Researchers stated that observing ethical legal requirements effectively and directly increases altruism between employees and organizational interactions and improves the fulfillment of organizational goals (Lee et al, 2014). In the present research, and based on the research of other researchers, the legal requirements include appropriate services, quality of service and trust.

\section{Research background}

Ismaili and Rahimi-Aghdam (2016) researched the role of ethical values in improving employees' performance with an emphasis on workplace spirituality. The results showed that workplace spirituality was associated with behavioral performance with a standard coefficient of 0.75 and a significance of 5.69 and with procedural performance with a standard coefficient of 0.21 and significance of 2.30. Teague shows that workplace spirituality plays a positive role in improving employees' performance at Tabriz University. Khodami \& Oslanloo (2015) researched designing a model of ethical behavior with emphasis on the role of organizational 
moral values. Findings based on the significant coefficients index showed that ethical values have a positive and significant relationship with all three dimensions of organizational justice. From the dimensions of organizational justice, only the dimension of interactive justice is related to both dimensions of organizational commitment and job satisfaction, and procedural justice is related only to organizational commitment. Both organizational commitment and job satisfaction have a positive relationship with ethical behavior.

The results showed that the research model was validated and demonstrated that: Organizational ethical values can lead to ethical behavior of employees through organizational justice, job satisfaction, and organizational commitment. Khodayari-Zarnagh et al. (2013) conducted research entitled the status of ethical values in hospital: a survey of educationalhealth hospitals of Tehran in 2013. Given the less desirable status of ethical values in these hospitals, health authorities should pay special attention to the triangle education (morality in hospitals), strategic attitude (morality in the health system), and fair compensation of services as key to morality improvement in the health system. The findings of the present research indicated that the ranking of components of professional morality in management can include responsibility, trust in God, honesty, trustworthiness, justice, and so on. In the sample, the factor of spirituality is in the first rank, intra-individual and extra-organizational factor in the second and third rank, intra-organizational and extra-individual factor in the next ranks. Finally, the professional morality of managers in this population is at a desirable level. Moghaddam \& Nasab, (2016) conducted research entitled the requirements and strategies of professional morality in higher education. The morality of using human beings as research subjects and morality related to conducting research. Adherence to the principles of professional morality by professors is of particular value given their effective role in learners' performance. The requirements of professional morality in higher education can be examined in the context of general higher education in the development process and the areas of teaching and research. Given the importance of morality in the aforementioned areas and the researches done, we can conclude that all teaching and research processes are ethical. Therefore, observing ethical requirements is a necessity.

Shah Ali et al. (2015) conducted a study entitled the model of implementing professional morality in Iranian organizations. In this research, the factors influencing professional morality are first extracted from the available sources based on the documentary method, and then, based on the Delphi technique, the most important influencing factors are refined by the relevant experts. In the next stage, the degree of impact, importance, and priority of each identified factor is determined and the relevant model is designed based on a systemic approach. The research findings indicate that factors affecting the implementation of professional morality in organizations can be studied in three individuals, organizational and environmental dimensions. Soltani (2016) conducted research entitled the role of moral excellence model in students and 
educational leaders' spiritual development. In his research, he argues that school leaders and students should adhere to accepted morals without exception to be successful; they must demonstrate their commitment to morality through tangible behavior. The ethical theory establishes a system of rules and principles that guides people in deciding what is right and wrong, what is good and evil. Morality and spirituality are of the important areas for the spiritual development of students and educational leaders. For the other hand, Mohageran \& Shohudi (2014) conducted research entitled modelling the relation of professional morality and spirituality at work to the social responsibility of nurses in public hospitals in Kermanshah. The results showed that there was a positive and significant relationship between professional morality and spirituality at work and social responsibility. Spirituality also has a mediating role in the relationship between morality and social responsibility. By acknowledging the mediating role of spirituality, professional morality has an indirect, positive and meaningful effect on nurses' social responsibility. Baharifar \& Javaherifar (2010) conducted research entitled examining the consequences of organizational ethical values (by studying organizational justice, organizational commitment, and organizational citizenship behavior).

The results above showed that the ethical values of the organization positively influence procedural justice and distributive justice. Procedural justice and distributive justice also have a positive effect on organizational commitment of employees. Organizational commitment positively influences employees' ethical behavior. Ethical behavior also positively affects the dimension of the chivalry and altruism dimension of organizational citizenship behaviors. Dabagh (2006) researched organizational ethical values among colleagues. The researchers stated in their research that the principles, the existence of ethical patterns and values in organizations lead to building trust among employees and enhancing organizational commitment among employees. According to this research, organizational culture, organizational commitment, and organizational justice are ethical symbols that must be present in organizations to build trust and organizational commitment in organizations. The results showed that there is a significant relationship between morality and organizational trust. Piang Tan (2017) researched ethical values and citizenship behaviors using the content analysis method. Researchers argued that accountability is one of the most important factors in citizenship behavior after that organizational commitment is also an important factor in ethical values. During the studies and analysis of the content of research, factors such as mutual respect, individual competence, trustworthiness, honesty, etc. were identified as ethical values governing citizenship behaviors. Chokprajakchat \& Nittaya (2017) conducted research entitled the implementation of legal requirements of professional morality for Thai government employees. The results showed that the overwhelming majority of government employees recognize these legal requirements, and one of the side findings of the research was that 
employees also disseminate these requirements to their colleagues to recognize them all new and older employees. These requirements include compliance with all laws and regulations of the organization, observance of discipline, respect and mutual trust, and so on. James \& Miller (2017) conducted a study entitled the legal requirements of morality in public health.

The legal requirements of public health morality have been approved by the American Public Health Association (APHA) for more than 10 years and have been very influential in this field. However, in this research, several agencies affiliated with the Ministry of Health have defined specific ethical guidelines for their organization and required staff to adhere to them. Researchers have argued that there are legal requirements to improve the organization's performance and to achieve better and faster organization goals that lead to increased public health at the society level. Explained requirements include organizational morality and discipline, medical professional morality, mutual respect and trust between employees and patients, and adherence to research and development professional morality. Stoeber \& Hongfei (2016) researched the relationship between moral perfectionism and moral values based on virtues and judgments. In this research, honesty, responsibility, justice, public trust, mutual respect, individual competence, trustworthiness, etc. were considered as ethical values and the relationship of each of these factors to moral perfectionism was measured and investigated. The results showed that moral values have positive and significant relationships with moral perfectionism. The research also showed that moral perfectionism was a personality trait and had a root in people's culture and influenced by one's moral values and attitudes.

\section{Conceptual model}

After examining the theoretical and background of the research as well as interviewing experts, our research has provided the model of organizational moral values comprised of two independent variables (predictors) of business morality patterns and legal requirements, and one dependent variable (criterion) of the organization's ethical values. Based on theoretical foundations and research background, each of the variables identified to explain the organization's ethical values model includes dimensions, components, and indices on which have commented many researchers over the years, and have provided definitions. Variable of work morality patterns includes three dimensions of social morality, professional morality, and individual morality. Variable of legal requirements includes three dimensions of service quality, good service and trust, and the ethical values of the organization include four dimensions of organizational justice, organizational commitment, the moral culture of the organization and social responsibility of the organization. Many scholars have commented on each of the identified variables, dimensions and components and have provided definitions that, together with the goals of the research ahead, constituted the ultimate model of the organization's ethical values. (Figure 1) has illustrated the conceptual model of the research (as proposed) on the 
conceptual bases and the theoretical framework of the research.

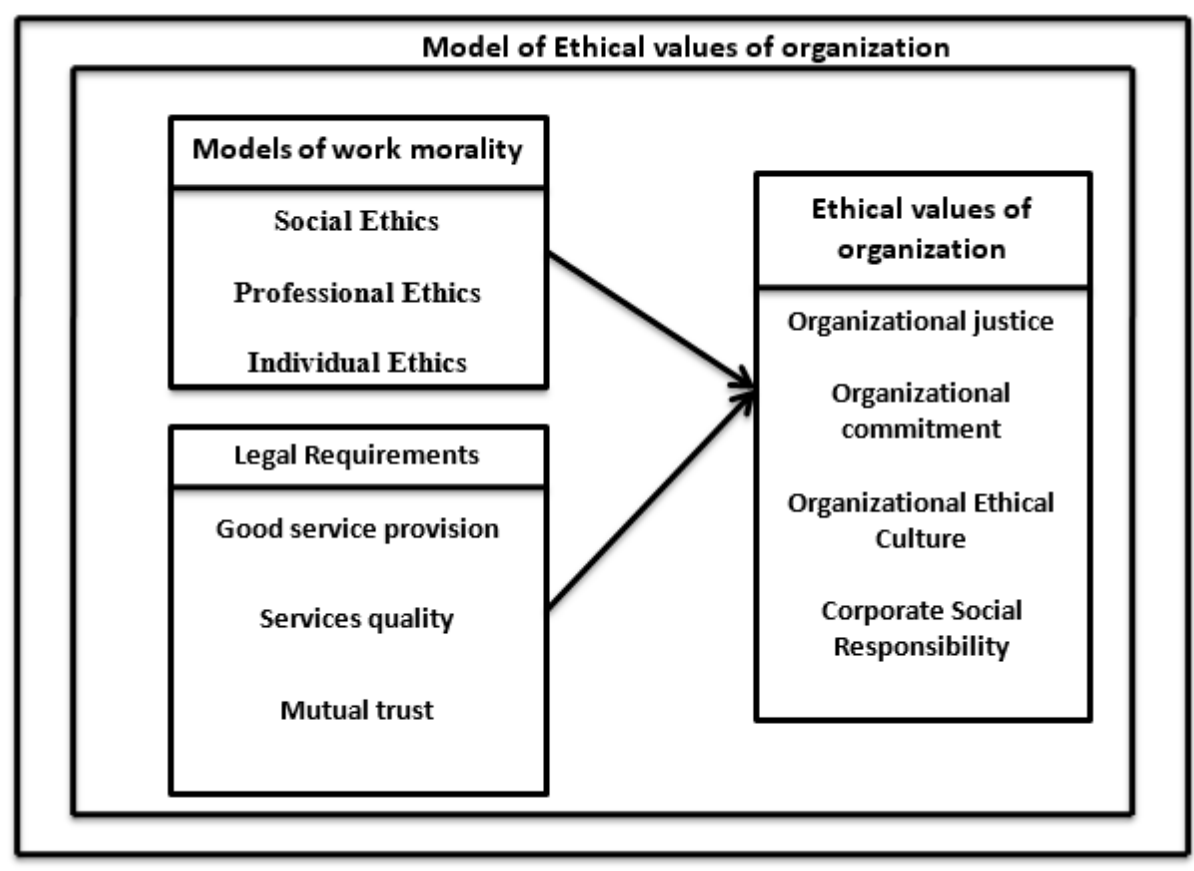

Figure 1. Conceptual model of research

According to the proposed model, the test questions will be formulated as follows:

- What are the dimensions of organizational ethical values?

- What are the dimensions of business morality patterns?

- What are the legal requirements?

- What is the model of measuring ethical values based on ethical patterns and legal requirements in the Kerman Tax Administration?

- What is the Structural Model of Ethical Values Based on Ethical Patterns and Legal Requirements in Kerman Tax Administration?

\section{Materials and Methods}

Based on the data collection, we can say that this research is a descriptive and exploratory one. The present research is also combined (quantitative, qualitative) type. Combined research is divided into several categories including angular, nested, explanatory and exploratory. Therefore, in this research, to determine and identify the components of the organization's ethical values, we review first the research literature and background, we tested and evaluated then the model using a quantitative approach. Therefore, given the above, the most appropriate approach for the research is the exploratory combined approach. Since the main purpose of the research is to investigate and explain the ethical values of the organization based on business ethical patterns and legal requirements in order to present a model in the 
Kerman Tax Administration, our statistical population includes 1. Experts and 2. Employees. The statistical population of this research includes the managers and employees of the Kerman Tax Administration. The Kerman Tax Administration currently has 19 managers and 708 employees.

\section{Experts}

This group includes managers and experts in the field of morality (organizational morality), which has been used to validate the model, as focus groups. In the qualitative stage, the interview stage, that is exploratory, the sampling was non-probable and at convenience. In this stage, the sample size was 11 individuals due to access restrictions.

\section{Managers and employees}

This group includes managers and employees of the Kerman Tax Administration; we used it in the process of pattern testing. According to statistics, there are 727 managers and employees of the Kerman Tax Administration. Because the type of research requires information to be obtained from specific individuals, ie specific types of people including managers (19) and employees (708) who can provide the desired information in the research (Salajeghe \& Sistani-Khanaman, 2010), they were selected as statistical samples.

\section{Results}

In the research literature, exploratory factor analysis is often used as part of the tool construction or validation process. What are the dimensions of organizational ethical values? In this research, we examined organizational ethical values based on four dimensions: organizational justice, organizational commitment, organizational ethical culture and social responsibility of the organization. To identify and explain the components of these four dimensions, we performed factor analysis for identifying the relationship and factor load between the components (17 components) and four dimensions. The results of the table show that: The relationship between the dimension of organizational justice and its components (4 components) is $0.68,0.87,0.70$ and 0.43 , respectively, which is very desirable. The relationship between the dimension of organizational commitment and its components ( 3 components) is $0.87,0.76$ and 0.58 , respectively, which is very desirable. The relationship between the dimension of organizational morality and its components ( 6 components) is $0.72,0.78,0.74$, $0.67,0.48$ and 0.78 , respectively, which is very desirable. The relationship between the social responsibility dimension of the organization and its components (4 components) is $0.79,0.71$, 0.83 and 0.83 , respectively, which is acceptable and highly desirable.

What are the dimensions of business morality patterns? In this research, the models of work morality are examined based on three dimensions: social morality, professional morality, and individual morality. To identify and explain the components of these three dimensions, 
factor analysis was performed to identify the relationship and factor load between the components (9 components) and three dimensions. The results of the table show that: The relationship between the social morality dimension and its components ( 3 components) is 0.79 , 0.82 and 0.31 , respectively, which is very desirable. The relationship between the dimension of professional morality and its components (3 components) is 0.50, 0.69 and 0.61, respectively, which is very desirable. The relationship between the dimension of individual morality and its components ( 3 components) is $0.53,0.31$ and 0.35 , respectively, which is acceptable.

\section{Discussion}

In this research, the legal requirements are examined based on three dimensions, quality of services, proper services provision and mutual trust. To identify and explain the indices of these three dimensions, factor analysis was performed to identify the relationship and factor load between the indices (13 indices) and three dimensions. The results (Table 1) show that: The relationship between services quality dimension and its indicators (items 1 to 4 ) are 0.66 , $0.42,0.66$ and 0.77 , respectively, which is acceptable and very desirable. The relationship between the dimension of appropriate service provision and its indicators is $0.69,0.77,0.82$ and 0.75 , respectively, which is acceptable and highly desirable. The relationship between the mutual trust dimension and its indices is $0.71,0.67,0.64,0.66$ and 0.48 , respectively, which is acceptable and highly desirable.

What is the model for measuring ethical values based on ethical patterns and legal requirements in Kerman Tax Administration? To answer this research question, the measurement model of these variables was drawn using AMOS23 software. 


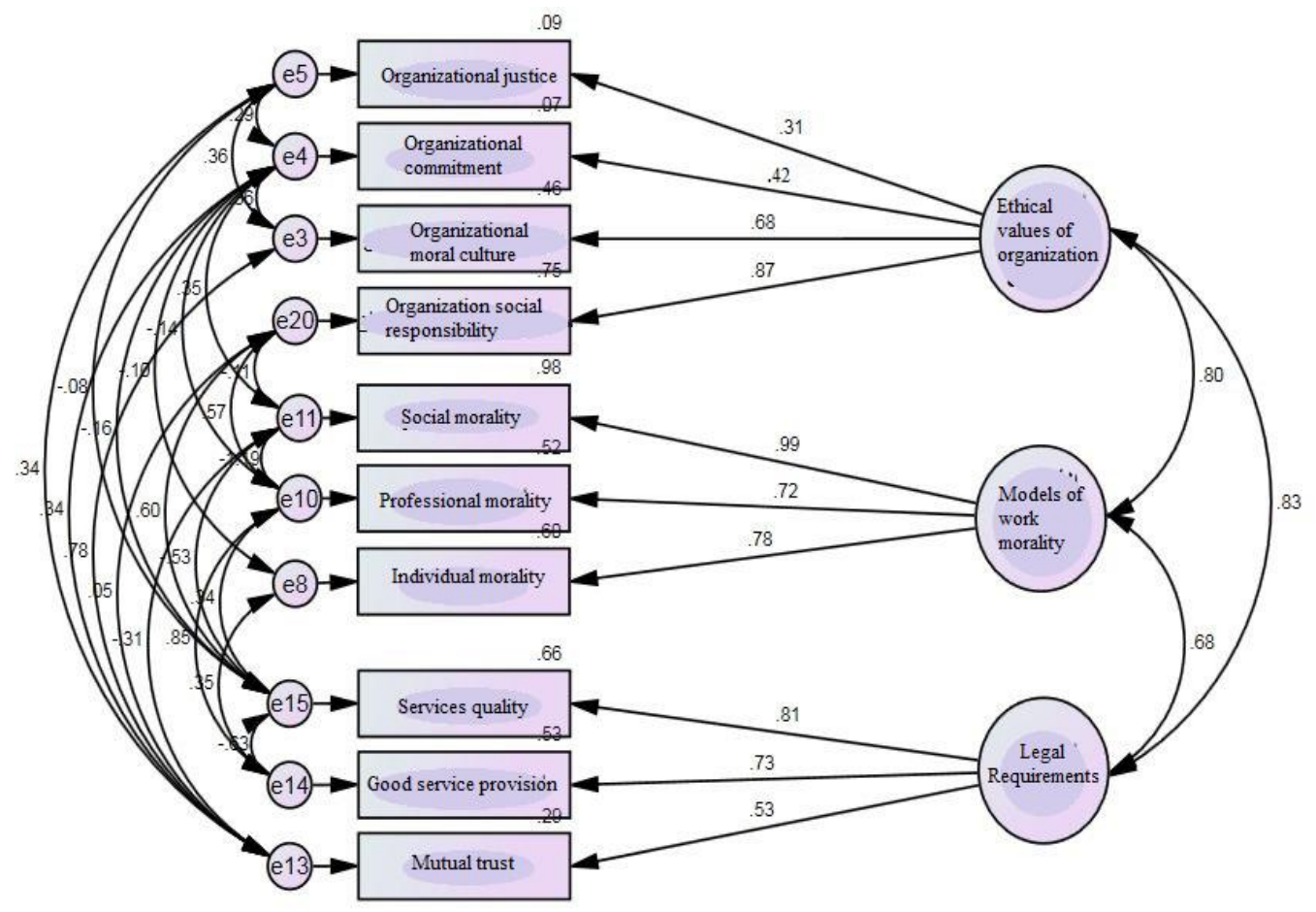

$\mathrm{CMIN}=30.91, \mathrm{P}=0.075, \mathrm{CMIN} / \mathrm{DF}=1.47, \mathrm{RMSEA}=0.036$

Figure 2. Model of measuring research variables

As we can see in (Figure 2), the correlation between the variables is not more than 0.9. So there is no need to merge or delete them. We also observe (Figure 2) that all factor loads are greater than 0.5 indicating that all dimensions have good factor validity. However, some factor loads are less than 0.5 (Table 1 )

Table 1

The goodness of fit of the research variables measurement model (4-11)

\begin{tabular}{ccccccccccccc}
\hline $\begin{array}{c}\text { Indices } \\
\text { of } \\
\text { pattern } \\
\text { fitness }\end{array}$ & CMIN & DF & CMIN/DF & NPAR & P & GFI & AGFI & IFI & TLI & CFI & NFI & RMSEA \\
\hline $\begin{array}{c}\text { Fitted } \\
\text { pattern }\end{array}$ & 10.63 & 10 & 06.1 & 45 & 0.387 & 0.99 & 0.95 & 1.00 & 0.99 & 1.00 & 0.99 & 0.016 \\
\hline $\begin{array}{c}\text { Desired } \\
\text { values }\end{array}$ & $\mathrm{df}=$ & - & $<3$ & - & $>0.05$ & $>0.90$ & $>0.90$ & $>0.90$ & $>0.90$ & $>0.90$ & $>0.90$ & $<0.08$ \\
\end{tabular}

What is the Structural Model of Moral Values Based on Ethical Patterns and Legal Requirements in Kerman Tax Administration? To answer this research question, after reviewing and validating the measurement model, using the AMOS23 software, we visualized the structural model of productivity of human force and investigated the relationships between hidden variables (which are the research questions) (Figure 3). 


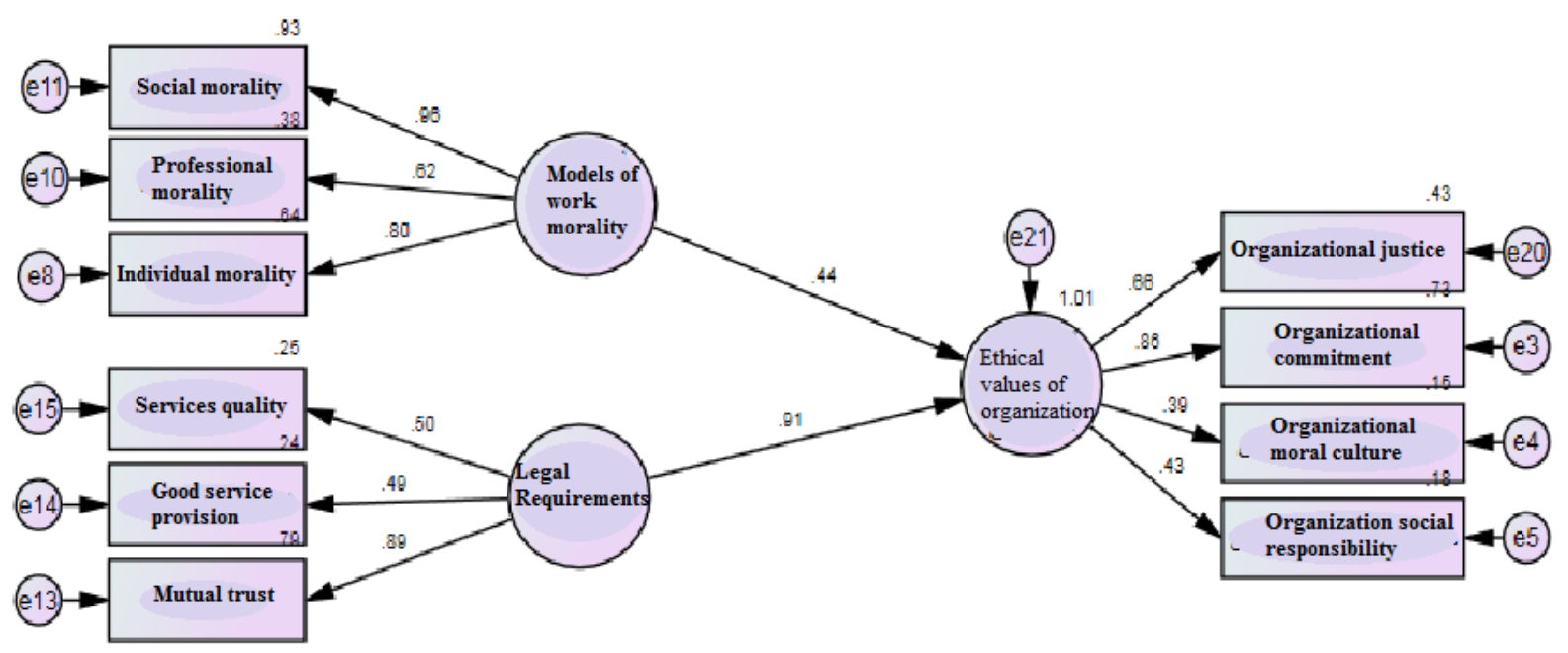

$\mathrm{CMIN}=10.83, \mathrm{P}=0.146, \mathrm{CMIN} / \mathrm{DF}=1.55, \mathrm{RMSEA}=0.047$

Figure 3. Structural Model of Research

Regarding the fit of the model concerning the fit indices, we can say that the factor analysis model is suitable to answer the question and the test of the main research hypotheses is of the goodness of fit. In other words, considering the appropriateness of fit indices, we can use this model to explain and design a model of ethical values based on ethical patterns and legal requirements in the Kerman Province Tax Administration (Table 2).

\section{Table 2}

The goodness of fit of the structural model of research variables (4-12)

\begin{tabular}{cccccccccccccc}
\hline $\begin{array}{c}\text { Indices } \\
\text { of Model } \\
\begin{array}{c}\text { Goodness } \\
\text { of fit }\end{array}\end{array}$ & CMIN & DF & CMIN/DF & NPAR & P & GFI & AGFI & IFI & TLI & CFI & NFI & RMSEA \\
\hline $\begin{array}{c}\text { Fitted } \\
\text { model }\end{array}$ & 10.83 & 7 & 1.55 & 48 & 0.146 & 0.99 & 0.93 & 0.99 & 0.98 & 0.99 & 0.99 & 0.047 \\
\hline $\begin{array}{c}\text { Desirable } \\
\text { values }\end{array}$ & $=\mathrm{df}$ & - & $<3$ & - & $>0.05$ & $>0.90$ & $>0.90$ & $>0.90$ & $>0.90$ & $>0.90$ & $>0.90$ & $<0.08$ \\
\end{tabular}

There is a positive and significant relationship between the variables of organizational morality patterns and values of work morality $(\mathrm{P}<0.05, \mathrm{t}=5.61, \beta=0.44)$. There is a positive and significant relationship between the variables of legal requirements and organizational ethical values $(\mathrm{P}<0.05, \mathrm{t}=5.43, \beta=0.91)$. 


\section{Discussion}

According to the results obtained from descriptive statistics, organizational ethical values include organizational justice, organizational commitment, organizational ethical culture, and organizational social responsibility. The results (Table 2) show that: The mean of the status of the variable "Organizational Ethical Values" from the point of view of the managers and employees of the Kerman Province Tax Administration was 3.85 and its standard deviation was 0.35 . From Score 5, the lowest score given by managers and employees of the Kerman Province Tax Administration was 2.59 and the highest was 4.59. Organizational moral values are defined as a subset of the organizational culture that illustrates the multidimensional interaction between formal and informal systems of behavioral control. These informal systems include a set of beliefs, norms, and actions that are common for individuals within an organization. In addition to these informal aspects, the organization's ethical values can also be expressed through more formal systems such as reward systems, policies, and procedures. When employees believe that policies and procedures are followed by managers and other people in the organization with ethical considerations, then ethical values are institutionalized in the organization. Managers, for example, may exhibit these values concerning ethical practices such as inciting ethical behavior and punishing immoral behavior (Baharifar \& Javaherifar, 2010).

The rationale behind the theory of focusing on ethical values, as a tool affecting employees' ethical behavior, is that individuals are expected to behave in a way that conforms to the values in the organization. Studies and researches illustrate the impact of ethical context on concepts such as job satisfaction, organizational commitment, intention to quit, and ethical conflict with managers and bosses. In other words, we can reasonably argue that moral context and environment influence employees' behaviors, including ethical behavior. In the role model of justice in organizations, Kuhn-Chorshe and Spector argue that organizational actions and activities exemplify the ethical behavior that enhances perceptions of distributive and procedural justice. Second, there are two main components of organizational justice, procedural justice, and distributive justice. Procedural justice refers to justice and equality of organizational policies and procedures used to determine rewards, while distributive justice refers to perceived equity and equality of actual outcomes or rewards. Past studies have shown that high levels of justice are positively associated with satisfaction, commitment, and trust. At the same time, low levels of justice are associated with poor performance, increased vigilance, and leaving job and job dissatisfaction. Therefore, both forms of justice are conceptually related to the ethical values of the organization. Both morality and organizational justice have a root in the concept of justice and include judgments about what is right and what is wrong. Individuals perceive their environment as fair and equitable so that these practices and laws are followed and the results of organizational policies and procedures are fair and equitable. We can, therefore, argue that 
the ethical values of the organization are positively related to procedural justice and distributive justice (Aghigh, 2016).

Patterns of work morality include the dimensions of social, professional and individual morality. The average status of "business morality patterns" from the viewpoint of managers and employees of Kerman province's tax administration was 3.24 and its standard deviation was 0.48 . On average out of 5 , the lowest score given to this variable by managers and employees of Kerman province tax administration was 1.65 and the highest was 4.28. In the field of social morality, the results of this research are consistent with researches conducted by Piang Tan (2017), Mirabrahimi \& Habibzadeh (2012), and Cheng (2017). In the field of professional morality, the results of this research are consistent with researches done by Piang Tan (2017), Mirabrahimi \& Habibzadeh (2012), Stoeber \& Hongfei (2016), y Cheng (2017). In the field of individual morality, the results of this study are consistent with those of Piang Tan (2017), Stoeber \& Hongfei (2016), Salajeghe \& Sistani Khanaman (2010).

Legal requirements include quality of services, appropriate service provision, and mutual trust. The average status of "legal requirements" from the point of view of managers and employees of Kerman province Tax Administration was 3.45 and its standard deviation was 0.54 . On average, out of 5 , the lowest score given to this variable by managers and employees of Kerman province Tax Administration was 1.95 and the highest was 4.52. The results of this research are consistent with researches carried out by Razaq et al. (2013), Khodami \& Oslanloo (2015), and Mousavi \& Arabshah-Karizi, (2014).

In the case of the measurement model of ethical values based on ethical patterns and legal requirements in the Kerman province Tax Administration, the correlation between variables is not more than 0.9. So, there is no need to merge or delete them. All factor loads are also greater than 0.5 , indicating that all dimensions have good factor validity.

Regarding the structural model of ethical values based on ethical patterns and legal requirements in the Kerman Province Tax Administration, the results of the model test showed that there is a positive and significant relationship between organizational ethical patterns and business moral values. There is also a positive and significant relationship between the variable of legal requirements and organizational ethical values. The present hypothesis is consistent with researches done by Dabagh (2006), Mohageran \& Shohudi (2014) and Tota \& Shehu, (2012).

\section{References}

Adeniji, S., Osinbanjo, F. \& Oludayo L. (2015). Effects of Workplace Ethics on Employees and Organisational Productivity in Nigeria, International Conference on African Development Issues (CU-ICADI): Social and Economic Models for Development 
Track, 24(3): 45-70.

Aghigh, A. (2016). Relationship between Some Ethical Variables and Organizational Health. Quarterly of Morality in Science and Technology, 16(3): 97-106.

Arianpour, M. \& Mehrabi, N. (2016). Requirements and strategies of professional morality in higher education system. Journal of Morality in Science and Technology, 11(4): 1-7.

Baharifar, A. \& Javaherifar, M. (2010). Investigating organization ethical consequences with organizational justice, organizational commitment and organizational citizenship behavior. Two Monthly of Police Human Development, 28(7): 63-77.

Cheng, Y. (2017). Anirban-Mukhopadhyay and Rom Y. Schrift, Do Costly Options Lead to Better Outcomes? How the Protestant Work Ethic Influences the Cost-Benefit Heuristic in Goal Pursuit. Journal of Marketing Research, 54(4): 636-649.

Chokprajakchat, S. \& Nittaya, S. (2017). Implementation of the code of professional ethics for Thai civil servants. Kasetsart Journal of Social Sciences, 38(1): 129-135.

Dabagh, S. (2006). Position of ethical propositions in the organizational decision-making system. Ideation of ethical decision-making based on the Ross system, 16(2): 214-230.

Ismaili, M. \& Rahimi-Aghdam, S. (2016). Role of ethical values in improving employee performance with emphasis on workplace spirituality. Quarterly of morality in science and technology, 11(2): 105-112.

James, C. \& Miller, T. (2017). Codes of Ethics in Public Health, International Encyclopedia of Public Health (Second Edition), 9(2): 71-83.

Khayat-Moghaddam, S. \& Tabatabai-Nasab, M. (2016). Components of Professional Morality in Management. Quarterly of Morality in Science and Technology, 6(2): 127-136.

Khodami, S. \& Oslanloo, B. (2015). Designing a model of employee ethical behavior with emphasis on the role of organization ethical values. Quarterly of Morality in Science and Technology, 20(1): 320-327.

Khodayari-Zarnagh, R., Abbasi, M., Arablou, J., Mobaseri, K., Turani, S. \& Esmaili, A. (2013). Investigating the Status of Ethical Values in Hospitals: A Survey in Educational Hospitals of Tehran in 2013. Journal of Bioethics, 10(3): 115-128.

Lee, Y., Joowon, C., Bo-young, M. \& Barry J. (2014). Codes of ethics, corporate philanthropy, and employee responses. International Journal of Hospitality Management, 39(6): 97106.

Mirabrahimi, A. \& Habibzadeh, N. (2012). Ethical Values in Organizations, First Annual Conference on Modern Management Sciences, Gorgan, 29(2): 89-100.

Mohageran, B. \& Shohudi, M. (2014). Modeling the Relationship between Professional Morality and Spirituality at Work with Social Responsibility among Nurses in Kermanshah Public Hospitals. Quarterly of Nursing Management, 19(7): 20-29.

Mousavi, M. \& Arabshah-Karizi, A. (2014). Relationship between morality and organizational 
excellence. Journal of Morality in Science and Technology, 9(2): 1-11.

Piang-Tan, B. (2017). Noor Banu Mahadir Naidu, Zuraini Osman, Moral values and good citizens in a multi-ethnic society: A content analysis of moral education textbooks in Malaysia. The Journal of Social Studies Research, 40(5): 136-147.

Rahimnia, F. \& Hoshyar, V. (2010). Impact of organizational justice on leaving job through josatisfaction. Journal of Modiriate Farda, (24): 23-42.

Razaq, S., Mushtaq, A., Sehrish, Z. \& Wajeeha, R. (2013). The impact of ethical values on the corporate social responsibility in public sector of Pakistan. European Journal of Business and Management, 5(3): 296-310.

Salajeghe, S. \& Sistani-Khanaman, F. (2010). Investigating the Relationship between Work Morality and Service Quality in Governmental Organizations, National Conference on Management and Leadership Challenges in Iranian Organizations, Islamic Azad University, Isfahan Science and Research Branch, 8(3): 69-85.

Shah-Ali, M., Rashidpour, A., Kavusi, I. \& Etebarian, A. (2015). The pattern of implementation of professional morality in Iranian organizations. Urban Management, 39(8): 393-406.

Soltani, I. (2016). Role of Ethical Excellence Model in the Spiritual Development of Students and Educational Leaders, First National Congress on Community Empowerment in the Field of Sociology, Educational Sciences, and Social and Cultural Studies, 17(6): 178190.

Stoeber, J. \& Hongfei, Y. (2016). Moral perfectionism and moral values, virtues, and judgments: Further investigations, personality and individual differences, 88(3): 26-35.

Tota, I. \& Shehu, H. (2012). The dilemma of business ethics. Procedia Economics and Finance, 40(2): 28-40.

Zameni, F. (2016). Investigating the relationship between managers' development of ethical behavior and organizational health. Quarterly of Bioethics, 20(6): 47-66. 